\title{
Increasing Population Density and Seed Production with Altitude in Eritrichium nanum (Boraginaceae)-an Arctic Alpine Obligatory Seeder
}

\author{
Heinrich Zoller*§ \\ Heiner Lenzin $\dagger$ \\ Hans-Peter Rusterholz $\$$ and \\ Jürg Stöcklin*\# \\ *Botanisches Institut, Universität Basel, \\ Schönbeinstr. 6 Basel, CH 4056 \\ Switzerland. \\ $\dagger$ Rheinfelderstr. 28 Birsfelden, CH 4127 \\ Switzerland. \\ heiner.lenzin@unibas.ch \\ \$NLU-Institut, St. Johanns-Vorstadt 10 \\ Basel, CH 4056 Switzerland. \\ hans-peter.rusterholz@unibas.ch \\ §heinrich.zoller@bluewin.ch \\ \#juerg.stoecklin@unibas.ch
}

\begin{abstract}
At 17 sites in the European Alps (2170-3310 m), the population density and seed production of the high alpine cushion plant Eritrichium nanum were investigated. Recruitment in this non-clonal species relies exclusively on seeds. The population density rose significantly with increasing altitude. A mean number of 368 seeds per $\mathrm{m}^{2}$ was observed. Whereas the quantity of the generative rosettes (metamers) was relatively constant, the annual seed production strongly varied and was found vulnerable, particularly in 1996, when it was suppressed by unfavorable weather conditions. In 1997 seed production again reached the usual level, when about the same amounts of seeds were recorded as in previous years, indicating the strong resistance of elevated $E$. nanum populations against the severe climate at high altitudes. With rising population density, E. nanum produces distinctly higher seed numbers. This increasing amount of seeds seems essential for the persistence of its uppermost populations. Our results indicate that it is caused by the rising number of rosettes/ surface and not a higher reproduction by single rosettes. Compared to other alpine species, the seed weight of E. nanum (average $0.76 \mathrm{mg}$ ) is high. Most of its neighboring species are clonal, producing much lighter seeds. The strategy of producing heavy seeds favors successful recruitment and appears to be decisive for an obligatory seeder such as E. nanum.
\end{abstract}

\section{Introduction}

Since the classic textbook about pollination of alpine forbs by Müller (1881), it has been assumed that dense carpets of flowers are a characteristic feature at high altitudes. Some few countings by Stäger (1913) at different altitudes in the Swiss Alps seemed to confirm this opinion. Günthart (1926) suggested increasing flower density in alpine meadows to be a fact. Besides several alpine plants (species of the Silenoideae and Alsinoideae and of the genera Saxifraga, Androsace, etc.), he named also two arctic dwarf shrubs: Cassiope tetragona and Diapensia lapponica. Later, countings of flowers or individuals per surface (population density) hardly took place, whereas altitudinal trends of clonal reproduction and autogamy were more often investigated. According to Hartmann (1955) and Stöcklin (1992), alpine grasslands and scree vegetation of the European Alps are characterized by $80 \%$ to $90 \%$ as clonal. These findings seem to indicate that clonal propagation is an effective strategy of plants living under the ecological stress of alpine habitats, in any case less risky than sexual propagation with flowering, pollination, and seed development, which waste too much energy in environments where the supply of nutrients is low. However, Söyrinki (1938) has pointed out in his basic study of the Scandinavian alpine flora, that only the dominant species in terms of their biomass strongly rely on vegetative propagation (grasses, sedges, and dwarf shrubs) but not the majority in terms of species number. Furthermore, Söyrinki (1938) found among plants inhabiting hostile places such as snowbeds the following obligatory seeders: Sibbaldia procumbens L., Veronica alpina L., Gnaphalium supinum L. This is in line with the observations of Grulke and Bliss (1985), Marchand and Reach (1980), and Billings (1974), who suggested that clonal propagation is less abundant in alpine than in arctic environments. After Stöcklin (1992), it appears that there is an abundance peak of clonal plants in the lower alpine belt (heaths of dwarf shrubs and meadows) and a reduction in frequency of vegetative multiplication at higher elevations in the upper alpine belt (alpine grasslands) and in the subnival zone (open screes; Kikvidze, 1993; Kikvidze and Nakhutsrishvili, 1998; Nakhutsrishvili, 1998) and finally in the nival zone (isolated individuals above the line of permanent snow; Gottfried et al., 1998). In fact, sexual propagation seems to be quite common among species occurring in the nival zone. In contrast to the opinion of Bliss (1971), some of these high alpine species are obligatory seeders such as Eritrichium nanum (L.) Schrader ex Gaudin (Zoller et al., 2002).

According to various textbooks, autogamy increases with higher latitude in the Arctic and at higher altitude in the mountains of the temperate zone. This is probably true for butterfly-pollinated flowers such as Dianthus, Primula, etc. (e.g., Erhardt and Jäggi, 1995). However, in some recent studies it was shown that there are different species which are heterogamous (e.g., Saxifraga oppositifolia L.; Gugerli, 1998, 2000) and in other cases simultaneously non-clonal (e.g., E. nanum; Zoller et al., 2001, 2002). Investigations about visitation rates to flowers of E. nanum and about its breeding system revealed that this species is fly-pollinated and mainly heterogamous. For an obligatory non-clonal plant such as E. nanum, the production of many large seeds seems to be indispensable for successful reproduction. There are several studies about seed weight in relation to environmental conditions (e.g., Baker, 1972; Urbanska and Schütz, 1986; Schütz and Stöcklin, 2001), but we could not find reliable information about the number of seeds produced by alpine forbs, especially by cushion plants. Furthermore, we know practically nothing about population densities and their relation to the seed production of high-alpine plants. Körner (1999) summarizes several case studies of clonal alpine plants in relation to their seed production. On the other hand, nothing is known about population density and seed production in obligatory seeders and about possible altitudinal trends. Therefore, the present study deals with the population density of E. nanum $\left(\mathrm{cm}^{2} / \mathrm{m}^{2}, \%\right.$ per plot) with its seed production $/ \mathrm{m}^{2}$ and its seed weight. These three dependent traits were investigated (1) in different populations, (2) at different altitudes, and (3) during several years (seed number). 
TABLE 1

List of investigated sites. The population density was investigated in all 69 plots; the seed number $/ \mathrm{m}^{2}$ in 13 permanent plots at sites 3, 5, 8, and 10; and the seed weight from material originating from sites $2,3,5,8$, and 10.

\begin{tabular}{|c|c|c|c|c|c|}
\hline Site & $\begin{array}{l}\text { Plots/site } \\
\text { (number) }\end{array}$ & Time of observation & $\begin{array}{l}\text { Altitude } \\
\text { (m) }\end{array}$ & $\begin{array}{l}\text { Longitude } \\
\text { (E) }\end{array}$ & $\begin{array}{c}\text { Latitude } \\
\text { (N) }\end{array}$ \\
\hline 1 Grauson (Grauson (Cogne, Val d'Aoste, Italy) & 2 & 1995 & $2820-2830$ & $07^{\circ} 24^{\prime}$ & $45^{\circ} 39^{\prime}$ \\
\hline 2 Zwischbergen (Saas, Wallis, Switzerland) & 16 & 1995 & $2700-3320$ & $08^{\circ} 01^{\prime}$ & $46^{\circ} 06^{\prime}$ \\
\hline 3 Claudio e Bruno (Formazza, Piemonte, Italy) & 5 & $1994,1996-1999$ & $2735-2750$ & $08^{\circ} 19^{\prime}$ & $46^{\circ} 25^{\prime}$ \\
\hline 4 Passo Cristallina (Bedretto, Ticino, Switzerland) & 2 & 1994 & $2570-2572$ & $08^{\circ} 31^{\prime}$ & $46^{\circ} 28^{\prime}$ \\
\hline 5 Pazolastock (Oberalp, Graubünden, Switzerland) & 6 & 1996 & $2700-2750$ & $08^{\circ} 39^{\prime}$ & $46^{\circ} 39^{\prime}$ \\
\hline 6 Passo Scuro (Leventina, Ticino, Switzerland) & 4 & 1994-1997, 1999 & $2480-2500$ & $08^{\circ} 42^{\prime}$ & $46^{\circ} 34^{\prime}$ \\
\hline 7 Grevasalvas (Maloja, Graubünden, Switzerland) & 1 & 1994 & 2690 & $09^{\circ} 43^{\prime}$ & $46^{\circ} 26^{\prime}$ \\
\hline 8 Grialetsch (Sils, Graubünden, Switzerland) & 1 & 1994 & $2690-2740$ & $09^{\circ} 47^{\prime}$ & $46^{\circ} 25^{\prime}$ \\
\hline 9 Piz Nair (St. Moritz, Graubünden, Switzerland) & 2 & 1992-1996 & $2825-2835$ & $09^{\circ} 47^{\prime}$ & $46^{\circ} 30^{\prime}$ \\
\hline 10 Piz Lagalb (Bernina, Graubünden, Switzerland) & 2 & 1992-1996 & $2950-2960$ & $10^{\circ} 01^{\prime}$ & $46^{\circ} 26^{\prime}$ \\
\hline 11 Sass Capell (Arabba, Dolomiti, Italy) & 2 & 1996 & 2500 & $11^{\circ} 49^{\prime}$ & $46^{\circ} 29^{\prime}$ \\
\hline 12 Porto Vescovo (Arabba, Dolomiti, Italy) & 4 & 1996 & $2500-2510$ & $11^{\circ} 52^{\prime}$ & $46^{\circ} 29^{\prime}$ \\
\hline 13 Gr. Hafner (Maltatal, Kärnten, Austria) & 2 & 1996 & $2575-2580$ & $13^{\circ} 23^{\prime}$ & $47^{\circ} 04^{\prime}$ \\
\hline 14 Faschauner Eck (Niedere Tauern, Kärnten, Austria) & 2 & 1996 & $2700-2780$ & $13^{\circ} 30^{\prime}$ & $47^{\circ} 01^{\prime}$ \\
\hline 15 Reitereck (Niedere Tauern, Kärnten, Austria) & 3 & 1996 & $2640-2680$ & $13^{\circ} 31^{\prime}$ & $47^{\circ} 01^{\prime}$ \\
\hline 16 Mangart (Tarvisio, Alpi Giulie, Italy) & 5 & 1998 & $2170-2300$ & $13^{\circ} 41^{\prime}$ & $46^{\circ} 26^{\prime}$ \\
\hline 17 Triglav (Planika, Julic Alps, Slovenia) & 9 & 1997 & $2340-2405$ & $13^{\circ} 50^{\prime}$ & $46^{\circ} 21^{\prime}$ \\
\hline
\end{tabular}

\section{Material and Methods}

Eritrichium nanum is a pioneer of screes and rocks in the Arctic and in the high mountains of the temperate zone growing in open hostile habitats. Its ramification depends exclusively on the primary axis. No adventitious roots are developed and therefore E. nanum is a strictly non-clonal species like many tap-rooted Fabaceae. The basically 2-carpellate ovaries of the members of the borage family develop maximally four individual nutlets per flower which are separately dispersed and for which in the following text the term "seed" will be used. Population density and seed production of E. nanum were studied in 69 plots of $1 \mathrm{~m}^{2}$ which were established at 17 different sites in the Italian, Swiss, Austrian, and Slovenian Alps (Table 1, Fig. 1)

\section{POPULATION DENSITY AND SEED NUMBERS}

The permanent plots were marked by short metallic sticks and/or stable rocks, both of which were sprayed with yellow paint. In order to make our investigations comparable, we used a metallic frame on which we stretched a nylon cord, dividing $1 \mathrm{~m}^{2}$ surfaces into one hundred $1 \mathrm{dm}^{2}$ sections (Zoller et al., 2001). In the field, the position and size of every $E$. nanum plant were accurately projected on paper copies of a $100 \mathrm{dm}^{2}$ grid (scale 1:10). By tracing the sizes on transparent graph paper, the area of each cushion could be determined in $\mathrm{cm}^{2}$. By this method it was possible to evaluate the total area of E. nanum in relation to the surface of the whole plot $\left(\mathrm{lm}^{2}\right)$. From the total surface $\left(\mathrm{cm}^{2}\right)$ covered by E. nanum its population density per $\mathrm{m}^{2}$ could be determined as $\%$ cover. To test if population density changed with altitude we measured the total surface of the E. nanum cushions in all 69 plots. At each site, one to several $1 \mathrm{~m}^{2}$ plots were selected in the center of occurrence where the frequency of $E$. nanum was maximal. The location of the sites is shown in Table 1 and Figure 1. The different number of plots per site reflects different population sizes and different topography. At sites 3 and 6 it was easy to choose four to five distant plots, while at sites 9 and 10 the slope was very irregular, conditions which made it difficult to install more than two distant plots. The unusually large occurrence of $E$. nanum at site 2 (Zwischbergen) made it possible to investigate population density, seed number, and seed weight of 16 different plots along an altitudinal gradient of $600 \mathrm{~m}$. In 13 permanent plots at 4 sites $(3,5,8$, and 10; Fig. 1, Table 1), all the developed inflorescences were harvested during 5 or $6 \mathrm{yr}$, respectively. The inflorescences were collected plant by plant and stored for each cushion in separate paper bags. In the lab we counted the numbers of inflorescences, flowers, fertilized flowers, and non-aborted seeds for each plot and cushion separately. Because E. nanum produces rosettes of which the size is equal to about $1 \mathrm{~cm}^{2}$, the number of flowers, fertilized flowers, and seeds are more or less proportional to the rosette number. Consequently, the counted inflorescences correspond to the number of the generative rosettes (metamers; White, 1979, 1984; Urbanska, 1992).

During the years 1992-1994 we visited the sites for harvesting in mid-September, late September, and early October (Zoller et al., 2001, 2002). Since seed dispersal begins in the second half of August, we were too late to obtain the total seed number. From 1995 to 1999, we harvested in mid-August at the latest, disregarding that some of the seeds were not yet ripe. Therefore, we do not have reliable seed numbers for the first 3 yr at Piz Lagalb and Piz Nair (Fig. 4a-b). After seed dispersal, fertilized flowers can easily be recognized by their spreading calyx lobes. This distinctive feature made it possible to count reliable numbers of fertilized flowers in all plots for every year.

\section{SEED WEIGHTS}

Altogether we weighed 468 seeds of E. nanum originating from sites 2, 3, 6, 9, and 10 (about 90 seeds per site) and 30 seeds of two species in the closely related genus Lappula: L. squarrosa (Retz) Dumort. and L. deflexa (Wahlenb.) Garcke from different sites in Switzerland. Furthermore, we weighted the seeds of several important neighboring species, such as Cerastium uniflorum Clairv., Minuartia sedoides (L.) Hiern., Saxifraga bryoides L., and S. exarata Vill. The seeds of the latter four species originated from three different and far distant sites in the Swiss Alps $(\mathrm{n}=30)$.

\section{Results}

\section{POPULATION DENSITY}

At sites including most of the geographic distribution of Eritrichium nanum, population density (\% cover) was always increasing with altitude (Fig. 2a-d). Population density increased in a set of 16 plots of $1 \mathrm{~m}^{2}$ investigated at Zwischbergenpass (site 2 in Fig. 1), 


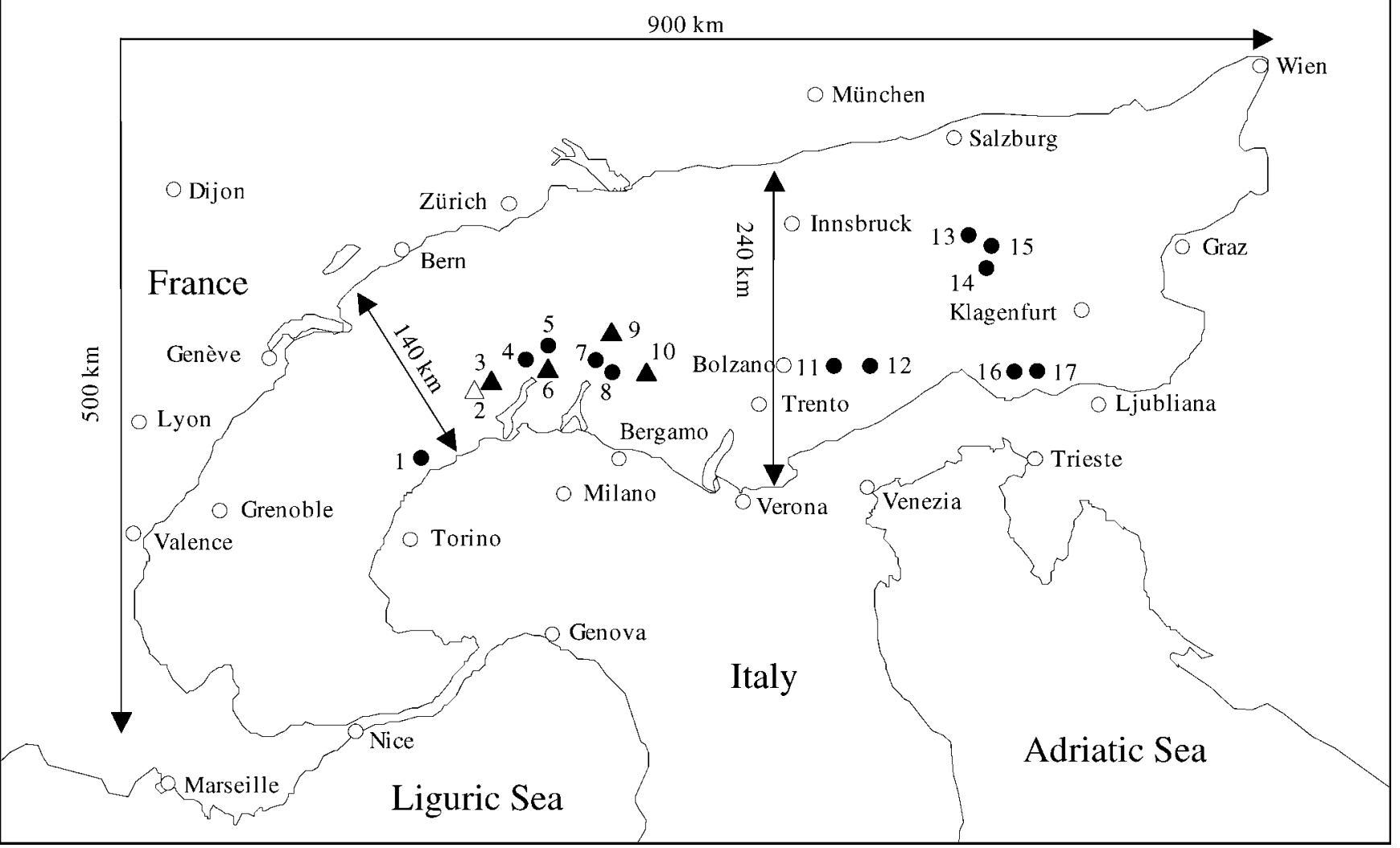

FIGURE 1. Map of investigated sites. Measurements: $\bullet$ (population density); $\triangle$ (population density and seed weight); $\boldsymbol{\Delta}$ (population density, seed weight, and seed number). (1) Grauson (Cogne, Val d'Aoste, Italy). (2) Zwischbergen (Saas, Wallis, Switzerland). (3) Claudio e Bruno (Formazza, Piemonte, Italy). (4) Passo Cristallina (Bedretto, Ticino, Switzerland). (5) Pazolastock (Oberalp, Graubünden, Switzerland). (6) Passo Scuro (Leventina, Ticino, Switzerland). (7) Grevasalvas (Maloja, Graubünden, Switzerland). (8) Grialetsch (Sils, Graubünden, Switzerland). (9) Piz Nair (St. Moritz, Graubünden, Switzerland). (10) Piz Lagalb (Bernina, Graubünden, Switzerland). (11) Sass Capell (Arabba, Dolomiti, Italy). (12) Porta Vescovo (Arabba, Dolomiti, Italy). (13) Grosser Hafner (Maltatal, Kärnten, Austria). (14) Faschaunereck (Niedere Tauern, Kärnten, Austria). (15) Reitereck (Niedere Tauern, Kärnten, Austria). (16) Mangart (Tarvisio, Alpi Giulie, Italy). (17) Triglav (Planika, Julic Alps, Slovenia).

from $0.45 \%$ at $2705 \mathrm{~m}$ a.s.l. to $2.9 \%$ at $3310 \mathrm{~m}$ a.s.l. $\left(\mathrm{R}^{2}=0.58\right.$, $P<0.001$ ); among the 13 permanent plots from $0.84 \%$ at $2500 \mathrm{~m}$ a.s.l. (Passo Scuro site 4 in Fig. 1) to 5.6\% at $2960 \mathrm{~m}$ a.s.l. (Piz Lagalb site 10 in Fig. $1 ; \mathrm{R}^{2}=0.74, P<0.001$ ); among 27 plots from the Eastern Alps from $0.65 \%$ at $2170 \mathrm{~m}$ a.s.l. to $2.7 \%$ at $2760 \mathrm{~m}$ a.s.l. $\left(\mathrm{R}^{2}=0.47\right.$, $P<0.001)$, and in $100 \mathrm{~m}$ sections between $2100 \mathrm{~m}$ and $3200 \mathrm{~m}$ a.s.l. from $0.2 \%$ to $3.2 \%\left(\mathrm{R}^{2}=0.66, P<0.001\right)$.

\section{SEED PRODUCTION}

The average number of seeds per fruit in the control plots of a selfing experiment at Passo Scuro was only 1.44 (Zoller et al., 2001, 2002). Nevertheless, we recorded an annual production of 368 seeds/ $\mathrm{m}^{2}$ (mean \pm 354 ) from the 13 permanent plots over a period of 2 (Piz Lagalb, Piz Nair) to 5/6 yr (Passo Scuro, Claudio e Bruno), respectively, whereas the mean number of seeds per rosette of E. nanum amounted to 1.23 during the same period (Table 2). It is noteworthy that the maximal seed production of 1354 per $\mathrm{m}^{2}$ (plot 5 at Claudio e Bruno, 1994) was about 450 times higher than the minimum of 3 seeds $/ \mathrm{m}^{2}$ (plot 2 at Passo Scuro, 1996). An even higher variability was noted for fertilized flowers (maximum about 900 times higher than minimum). Smaller but nevertheless considerable differences were recorded for the flower numbers (maximum about 110 times higher than minimum) and for the inflorescences (maximum 50 times higher than minimum). A significantly greater number of seeds was produced at higher altitudes (Fig. 3). Undoubtedly this increased seed production is parallel to the rising population density with increasing elevation. On the other hand, the seed production per rosette of $1 \mathrm{~cm}^{2}$ surface is independent from the altitude $\left(\mathrm{R}^{2}=0.017, P=0.673, \mathrm{n}=13\right)$.

The annual number of inflorescences, i.e., generative rosettes, was noticeably constant, whereas the production of flowers and seeds was much more irregular over the years (Fig. 4a-c). Especially in 1996, the amounts of fertilized flowers and seeds were extremely low in all the eight plots of Passo Scuro, Piz Nair, and Piz Lagalb. In the year after this depression (1997) the sexual performance measured in the four plots of Passo Scuro reached again similar levels as before 1996 or was even higher (Fig. 4c). However, in the plots of Claudio e Bruno no

TABLE 2

Seed production of Eritrichium nanum (1992-1999).

\begin{tabular}{lcccc}
\hline \hline \multicolumn{1}{c}{ Organ } & Minimum & $\begin{array}{c}\text { Average } \pm \mathrm{SD} \\
\text { per plot }\left(\mathrm{m}^{2}\right)\end{array}$ & Maximum & $\begin{array}{c}\text { Mean number per } \\
\text { rosette of E. nanum* }\end{array}$ \\
\hline Inflorescences & 16 & $203 \pm 240$ & 777 & 0.77 \\
Flowers & 27 & $780 \pm 692$ & 3648 & 2.84 \\
Fertilized flowers & 3 & $325 \pm 318$ & 2709 & 1.23 \\
Seeds (nutlets) & 3 & $368 \pm 354$ & 1354 & 1.40 \\
\hline
\end{tabular}

* Based on a mean rosette size of $1 \mathrm{~cm}^{2}$. 
a.
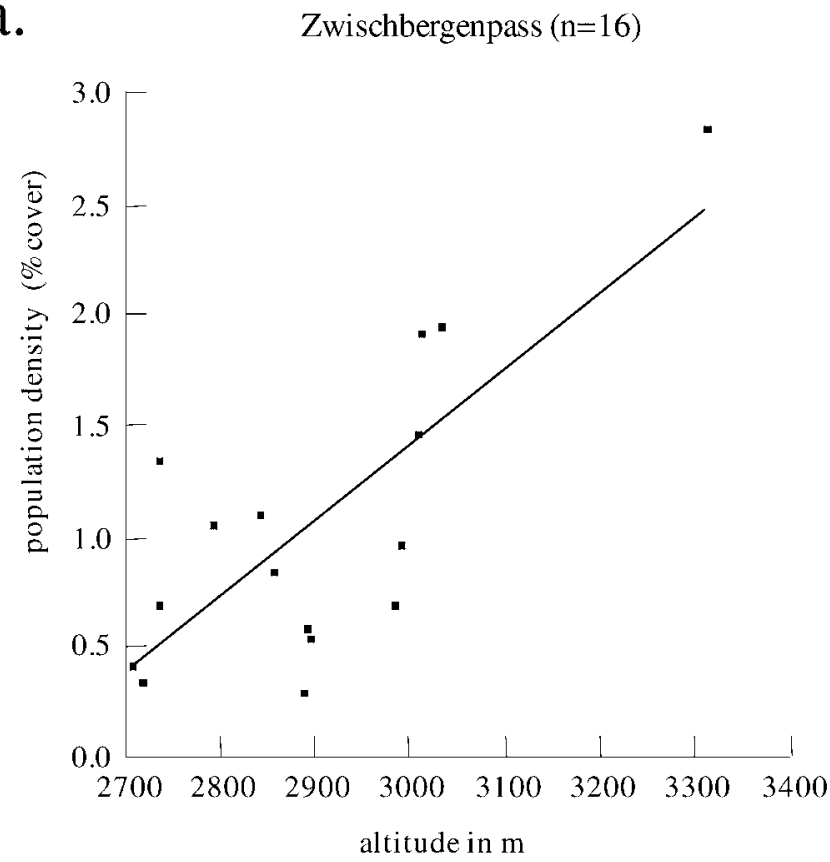

c.

Eastern Alps $(n=27)$

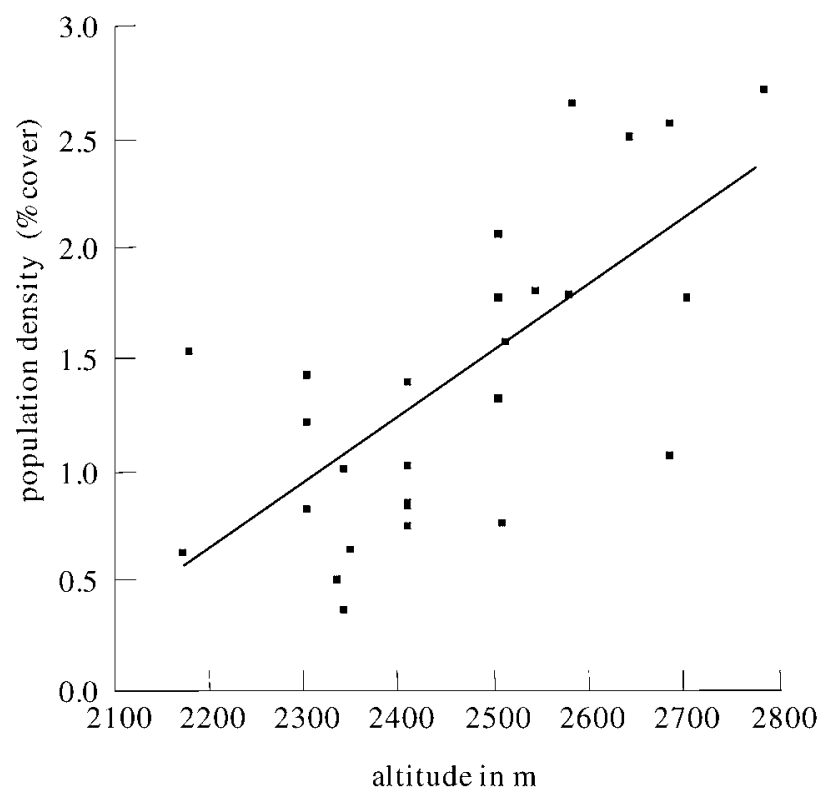

b. Permanent plots $(n=13)$

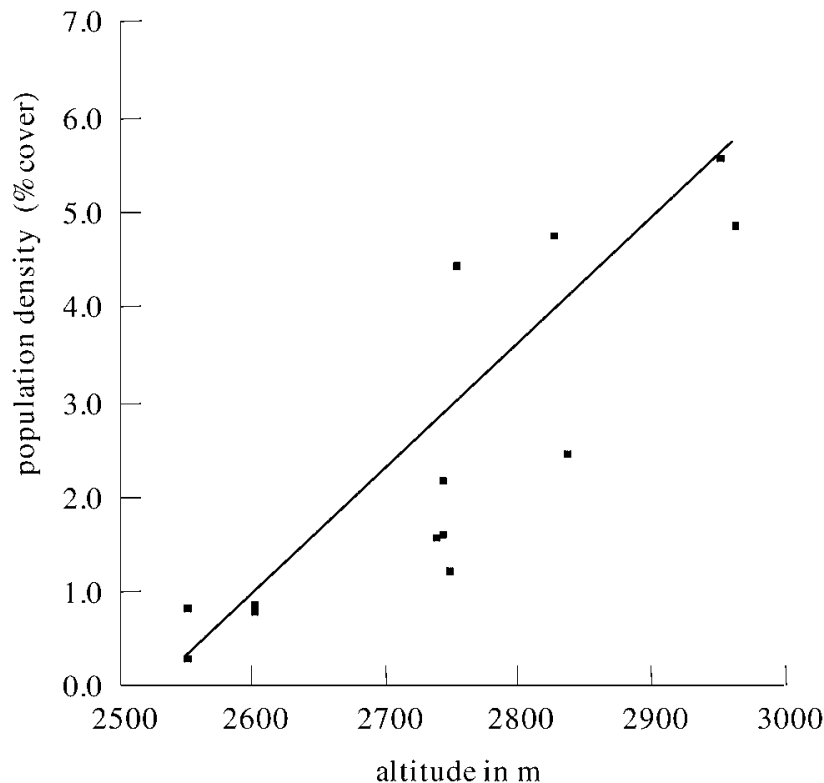

d.

Summary (means per $100 \mathrm{~m}$ sections, $\mathrm{n}=11$ )

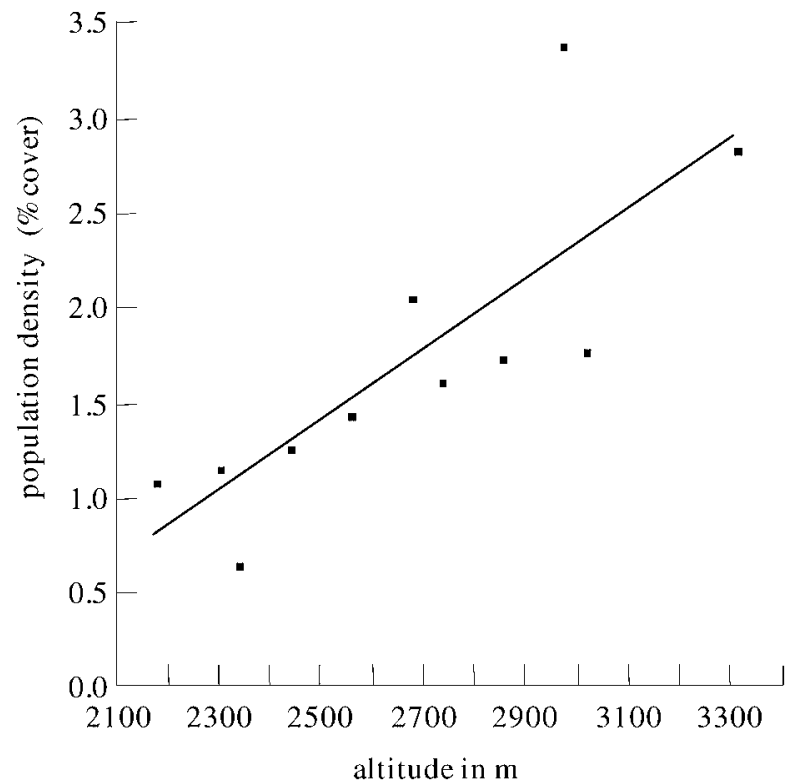

FIGURE 2. Population density of Eritrichium nanum in plots of $1 \mathrm{~m}^{2}$ (\% cover) with altitude in the European Alps. (a) Zwischbergenpass: data of 1996. The population density increases significantly with increasing altitude $\left(R^{2}=0.581, n=16, \mathrm{P}<0.001\right)$. (b) Permanent plots: data of 1995; Claudio e Bruno, 1996. The population density increases significantly with increasing altitude $\left(R^{2}=0.741, n=13, \mathrm{P}<0.001\right)$. (c) Eastern Alps: data of 1996; Triglav, 1997; Mangart, 1998. The population density increases significantly with increasing altitude $\left(R^{2}=0.471, n=27, \mathrm{P}<\right.$ 0.001). (d) Summary: mean per 100 m section. Data of 1995; Passo Cristallina, 1994; Zwischbergen, Claudio e Bruno, Dolomits, and Austrian Alps, 1996; Triglav, 1997; and Mangart, 1998 (see Table 1). The mean population density per 100 section increases significantly with increasing altitude $\left(R^{2}=0.659, n=11, \mathrm{P}<0.01\right)$.

corresponding depression of the generative reproduction was observed (values not shown).

\section{SEED WEIGHTS}

The seed weights of E. nanum varied between $0.4 \mathrm{mg}$ and $1.4 \mathrm{mg}$, with an average value of $0.76 \mathrm{mg}$. The seeds of $E$. nanum are significantly heavier than those of its most frequent neighboring species (Fig. 5) in which the mean weights vary from $0.03 \mathrm{mg}$
(Saxifraga bryoides, $S$. exarata) up to $0.24 \mathrm{mg}$ (Cerastium uniflorum) and $0.35 \mathrm{mg}$ in Silene acaulis (L.) Jacq. (Chambers, 1995), respectively. On the other hand, the seed weights of Lappula deflexa and $L$. squarrosa, closely related to E. nanum but living at lower altitudes, amounted to more than $1 \mathrm{mg}$. Obviously they are distinctly heavier than the seeds of E. nanum (Fig. 5). Among the seeds of E. nanum we observed a significant trend of decreasing mean weight associated with increasing altitude $\left(\mathrm{R}^{2}=0.51, P<0.01, \mathrm{n}=13\right.$; Fig. 6$)$. 


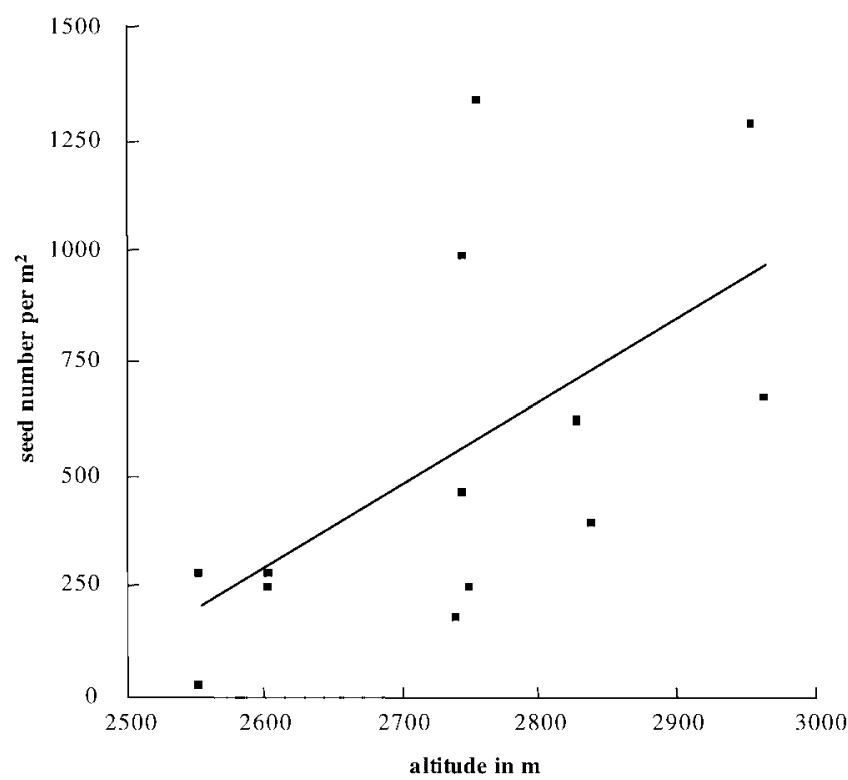

FIGURE 3. Seed number of Eritrichium nanum in 13 permanent plots of $1 \mathrm{~m}^{2}$ in relation to increasing altitude in the Swiss Alps (data of 1995; Claudio e Bruno, 1996). The seed number increases significantly with increasing altitude $\left(R^{2}=0.36, n=13, \mathrm{P}<0.05\right)$.

\section{Discussion}

\section{POPULATION DENSITY}

Since Müller (1881), Stäger (1913), and Günthart (1926) suggested that alpine forbs produce more flowers and accordingly higher numbers of possible descendants than lowland plants, this opinion has never been tested by systematic studies. The trend can be caused either by increasing allocation to flowers or by increasing population density. We found increasing population densities in Eritrichium nanum from dense grasslands at the lower alpine belt to open screes near the permanent snow line. We thereby confirm for the first time quantitatively the above suggestions by Müller (1881). In the case of Eritrichium nanum, the increasing population density was investigated over an altitudinal range of more than $1000 \mathrm{~m}(2170-3310 \mathrm{~m})$ and is probably explained by the distinctly diminishing competition from other species in the open screes at higher altitudes. In particular, sedges and grasses such as Carex curvula All. and Festuca halleri All. or Elyna myosuroides (Vill.) Fritsch, which are typical for dense grasslands, are more and more disconnected above $2700-2800 \mathrm{~m}$. It seems likely that by using a similar method, a corresponding trend could be found for other cushion plants like Silene exscapa All., Cerastium uniflorum, Androsace alpina (L.) Lam., etc. In the case of E. nanum, the uppermost populations were four to six times denser than the lowest of this species. However, their total cover reaches rarely more than $15 \%$.

\section{SEED NUMBERS}

It is common in studies dealing with sexual reproduction of plants to calculate the number of developed seeds in relation to shoots, individual rosettes, or the seed bank in the soil. Seed production of Eritrichium nanum seems to be clearly correlated with its population density and is therefore best counted in defined surfaces (e.g., $\mathrm{lm}^{2}$ plots). Corresponding to the increase in population density at higher altitudes, the numbers of seeds were also increasing (Fig. 3). Undoubtedly this increasing number of seeds is related to the increasing surface covered by E. nanum. On the other hand, by calculating the seeds per $\mathrm{cm}^{2}$ surface of E. nanum, it could be shown that the seed production per rosette is independent of altitude. From this, it follows that the increasing number of seeds with altitude is caused by a higher number of rosettes per surface and not by an increased investment in reproduction by single rosettes. The increased seed production at higher altitudes seems to be essential for E. nanum, maintaining stable populations in the subnival belt just below the permanent snow line. Seed numbers $/ \mathrm{m}^{2}$ at $2950-2960 \mathrm{~m}$ at Piz Lagalb were at least two to three times higher than at Passo Scuro at 2550 $2605 \mathrm{~m}$ (Fig. 3), in spite of the strongly limited seed production per flower within the family of Boraginaceae (maximal 4 seeds/flower), which seems disadvantageous for an obligatory non-clonal species like E. nanum. There are clonal species with up to seven times higher seed production/fruit than E. nanum, such as Epilobium fleischeri Hochst. (Stöcklin and Favre, 1994). Saxifraga bryoides, another clonal species occurring together with $E$. nanum, produces at least 20 times more seeds per fruit (counting in 2002, mean $=119 \pm 43, n=5$ ). Nevertheless, this taxonomically restricted seed reproduction in E. nanum is sufficient due to the relatively high seed weight guaranteeing a high rate of recruitment (Zoller and Lenzin, 2004).

Day et al. (1999) showed on an Antarctic island that seed weight and seed numbers of the cushion plant Colobanthus quitensis are strongly influenced by temperature. The capsules of this species produced under experimental warming $45 \%$ more seeds that were $11 \%$ heavier. We did not study cushions of E. nanum under experimental conditions, but our countings (Fig. 4a-c) make it evident that the seed production of E. nanum is vulnerable and can be affected by unfavorable weather conditions, such as in 1996 when seed production was almost completely suppressed in several plots. According to the 1996 report of the Swiss Central Meteorological Institution (1997), the winter of 1995/1996 was almost without snow even at high altitudes and was followed by an extremely dry spring, then a hot and dry period during June and July which ended abruptly in the second half of August, when a polar air current brought early snow and icy temperatures. These exceptional weather conditions were much more pronounced east of the "Gotthardpass" than farther west. Therefore, it seems plausible that the eastern study sites (Passo Scuro, Piz Nair, and Piz Lagalb) had a heavily depressed seed production in this year, whereas, at the westernmost site (Claudio e Bruno), seed development was unimpaired. Rauh (1939), cited by Körner (1993) and Körner and de Moreas (1979), observed that alpine cushion plants lose only relatively little water from their reduced leaf surface and consequently suffer little from water stress. That E. nanum was not seriously damaged, either by the persistent drought or the sudden frost in 1996, is demonstrated by its high seed production in 1997 at Passo Scuro which reached in all four plots similar levels as in previous years (Fig. 4c). However, it is worth mentioning that the seeds of E. nanum ripen in inflorescences which are often elongated up to $6 \mathrm{~cm}$ and therefore less protected than in most alpine cushion plants with their extremely reduced stems and with fruits developing within the cushion or less than $1 \mathrm{~cm}$ above its surface, i.e., Minuartia sedoides, Silene acaulis, S. exscapa All., Androsace alpina (L.) Lam., A. helvetica (L.) All., A. vandellii (Turra) Chiov., etc. We suppose that the extreme weather conditions, particularly the general drought to which the inflorescences, flowers, and ripening seeds of E. nanum were exposed during 1996 , may have contributed to the unusually low seed production in this year.

\section{SEED WEIGHTS}

Evidently diaspore weight is taxonomically constrained (Urbanska and Schütz, 1986; Thompson and Rabinowitz, 1989). Therefore, ecologically significant differences are best studied within the same genus or family. Several factors causing variability in seed weights of alpine plants have been discussed: (1) Pioneer plants are small seeded, 
a.

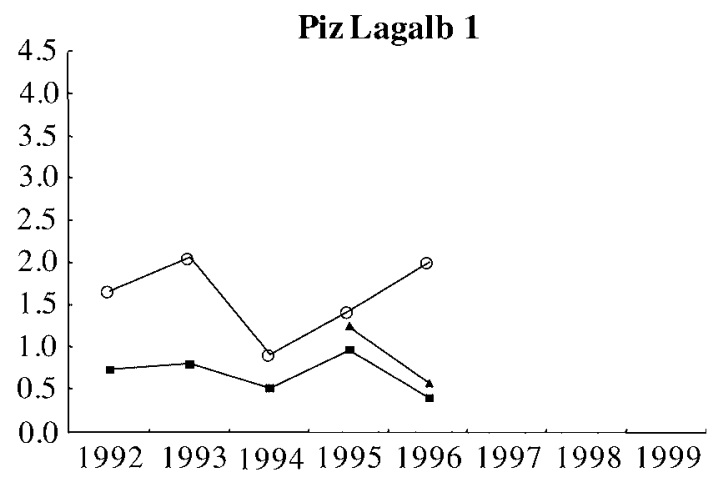

Piz Lagalb 2

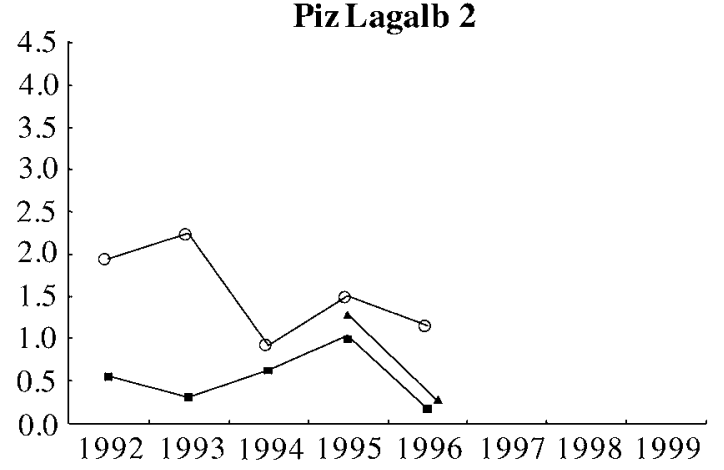

b.

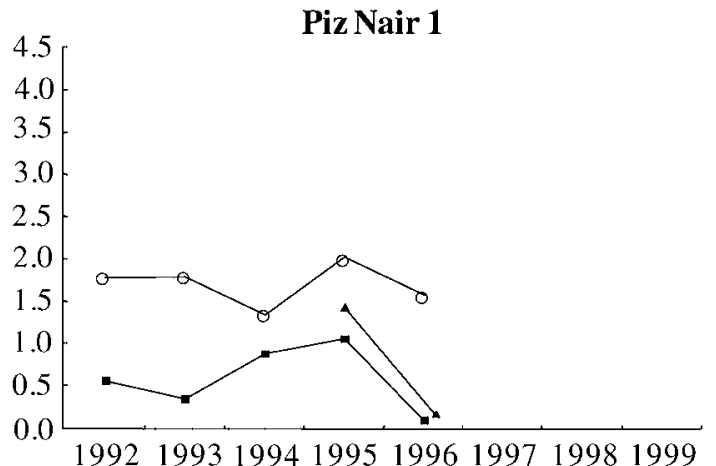

Piz Nair 2

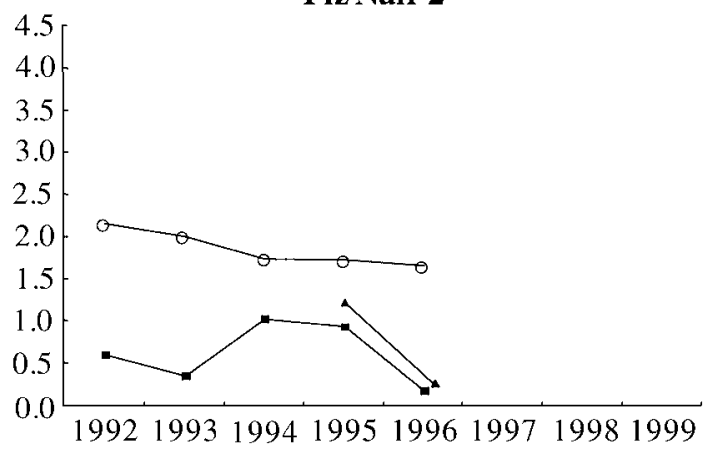

c.

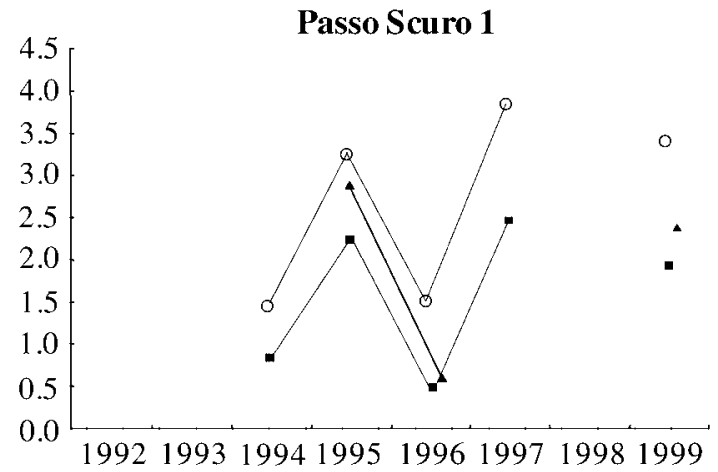

Passo Scuro 3

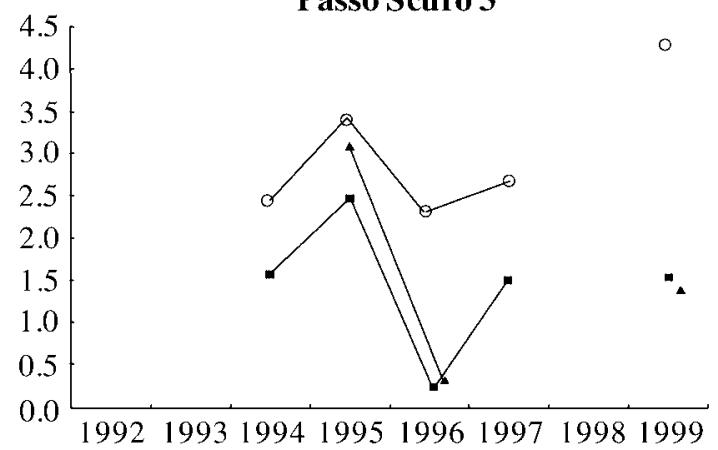

Passo Scuro 2

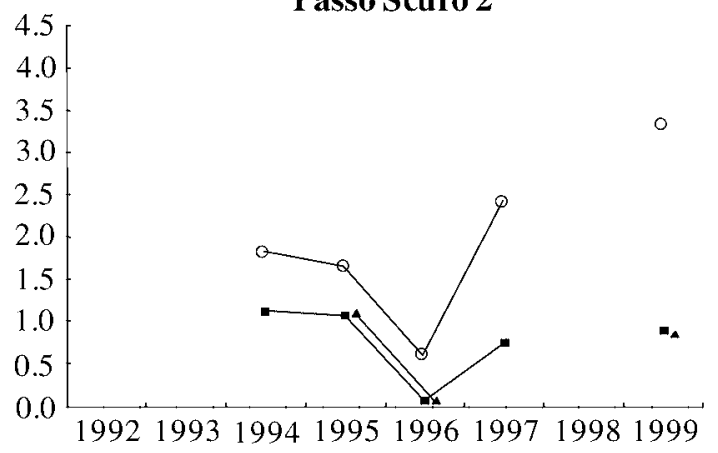

Passo Scuro 4

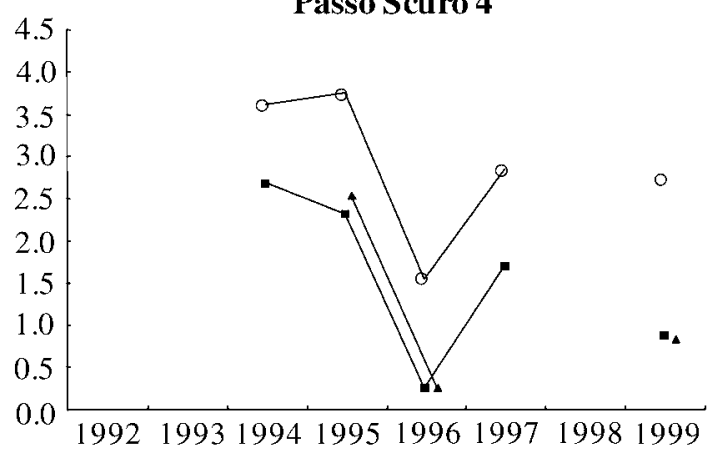

FIGURE 4. Annual variation of flowers, fertilized flowers and seeds of Eritrichium nanum in 8 plots at 3 sites: (a) Piz Nair (1992-1996), (b) Piz Lagalb (1992-1996), (c) Passo Scuro (1994-1997, 1999). 


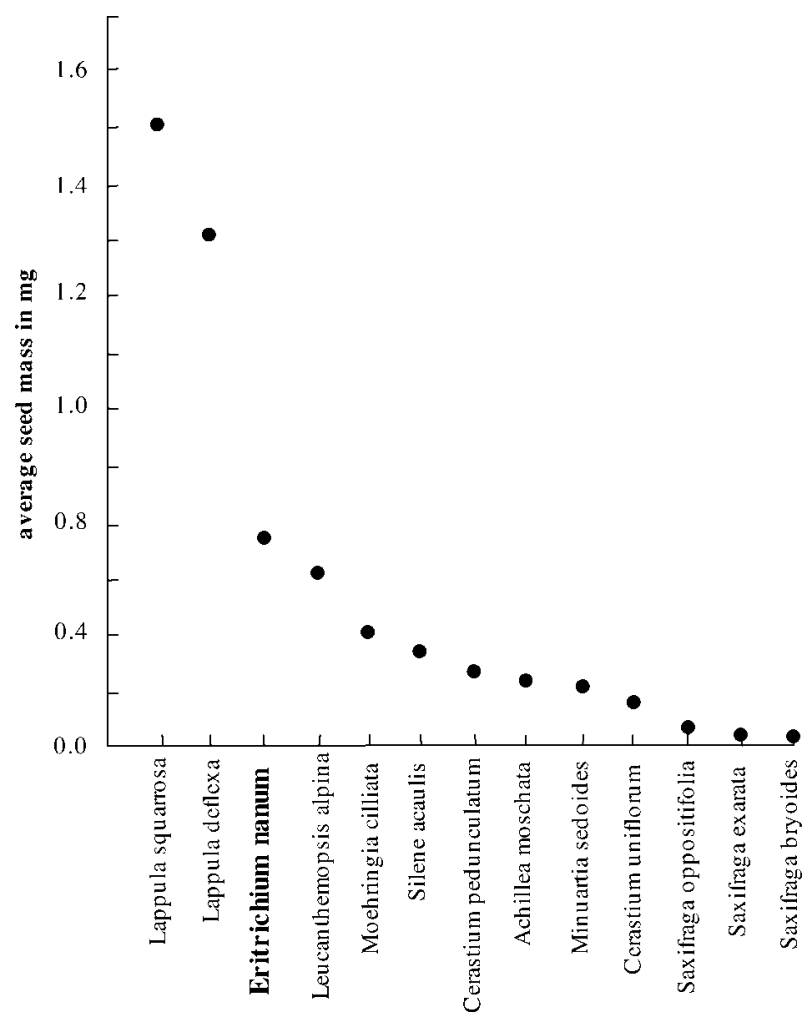

FIGURE 5. Mean seed weight of Eritrichium nanum, of related species (Lappula squarrosa and L. deflexa, to the left) and of species from the same habitat (Leucanthemopsis alpina, Moehringia cilliata, Silene acaulis, Cerastium pedunculatum, Achillea moschata, Minuartia sedoides, Cerastium uniflorum, Saxifraga oppositifolia, Saxifraga exarata and Saxifraga bryoides, to the right).

whereas plants of climax vegetation are heavy seeded (Kerner, 1871; Salisbury, 1974). (2) Late flowering alpine plants produce smaller seeds than earlier flowering species (Körner, 1999). (3) Seed weights of alpine forbs are related to altitude (Baker, 1972; Schütz and Stöcklin, 2001). (4) Compared with other alpine species, the seeds of Eritrichium nanum range among the heavy ones (Fig. 5). Only some Asteraceae, few Apiaceae, and Fabaceae develop distinctly heavier diaspores (Harper et al., 1970; Urbanska and Schütz, 1986; Chambers, 1995). Therefore, the considerably high establishment after $1 \mathrm{yr}$ (more than $40 \%$ of all seeds) and successful recruitment after 5 yr (more than 25\%; Zoller and Lenzin, 2004) of seedlings of E. nanum appear to be correlated with its heavy seeds, a strategy which seems to be essential for a high-alpine, obligatory, non-clonal species (Venable and Brown, 1988, 1993). At any rate, this strategy of E. nanum, a high alpine long-living pioneer of open screes, differs principally from all the invasive short-living lowland pioneers which produce many light seeds and seedlings of high mortality (Harper, 1990; Grime, 2001).

The heavy nutlets of E. nanum do not confirm the opinion that pioneer plants always produce small seeds. Furthermore, longflowering $E$. nanum is not in line with the smaller seeds developed by late-flowering plants (Körner, 1999). On the other hand, seed weights of E. nanum decreased with altitude (Fig. 6). This is most likely caused climatically by a reduced length of the vegetation period. A similar intraspecific trend of decreasing seed weights was found by Baker (1972) in California. However, lighter seed weights at the higher and highest sites may be in contrast to the above-mentioned strategy of heavy seeds favoring successful establishment. The observed trend may partly explain the large variability $(0.4-1.4 \mathrm{mg})$ of the E. nanum seeds. Furthermore, it seems conclusive that the seed weights are

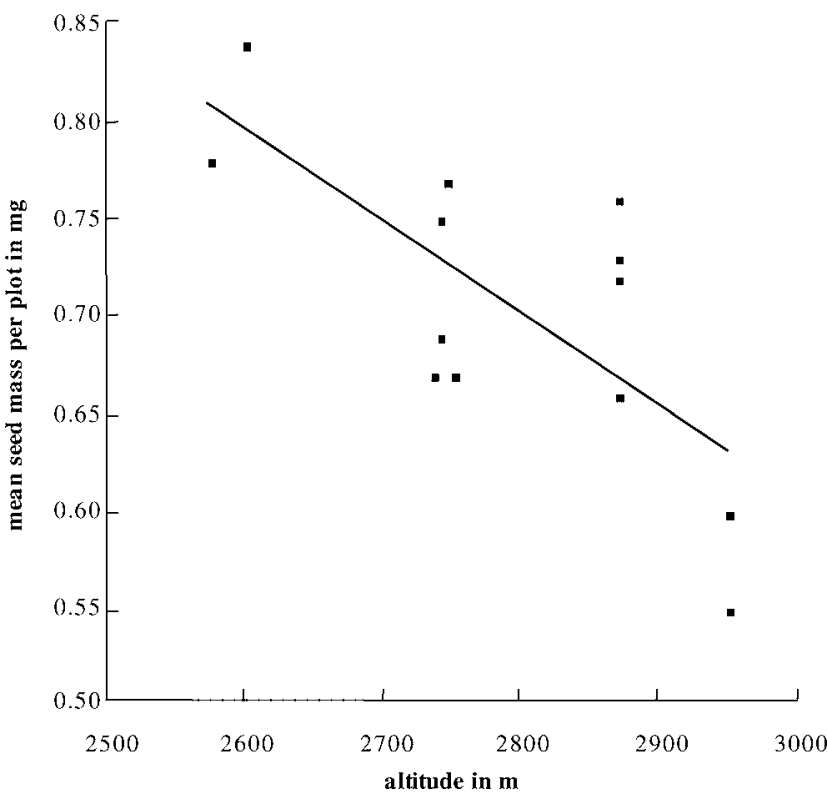

FIGURE 6. Mean seed weight ( $m g, n=50)$ of Eritrichium nanum in 13 plots of $1 \mathrm{~m}^{2}$ in relation to altitude in the European Alps (data of $\left.1990-2001 ; R^{2}=0.52, n=13, \mathrm{P}<0.01\right)$.

distinctly lighter in flowers developing three or four seeds than in those with only one (Zoller, unpublished).

Recently, Schütz and Stöcklin (2001) observed a distinct trend towards higher seed weight corresponding with increasing altitude in the genera Crepis and Senecio (Asteraceae). Trying to confirm this trend for E. nanum and its most closely related species in the genus Lappula, we found the weights of the lowland species were significantly heavier, i.e., just the opposite of the observed trend among species. Nevertheless, we assume that the significantly higher seed weights in alpine species at the generic level, observed in the Asteraceae and preliminarily in the Apiaceae and Caryophyllaceae reflect a general trend, whereas the inverse trend found in the family Boraginaceae may be rather exceptional. In the relationship of the tribe Eritrichioideae (Fig. 5), it may be connected with the life span of the cushions of E. nanum which is much longer than in the annual or short perennial Lappula species.

\section{Acknowledgments}

We thank all the persons who accompanied us on many excursions or gave us information about Eritrichium nanum habitats: Dr. E. Erschbamer (Dolomiten), D. Haas (Gr. Hafner, Niedere Tauern, Dolomiten), Prof. Dr. L. Kutschera (Kärnten), Dr. E. Lichtenegger (G. Hafner), R. Reinalter (Oberengadin). Special thanks go to Dr. A. F. Mark (University of Otago, Duneden, New Zealand) for his helpful review. The research was financially supported by the "Stiftung zur Förderung der Pflanzenkenntnis Charles Simon" in Basel.

\section{References Cited}

Baker, H. G., 1972: Seed weight in relation to environmental conditions in California. Ecology, 53: 997-1010.

Billings, D. W., 1974: Arctic and alpine vegetation: plant adaptations to cold summer climates. In: Ives, J. D., and Barry, R. G. (eds.), Arctic and alpine environments. London, Methuen, 403-443.

Bliss, L. C., 1971: Arctic and alpine plant life cycles. Annual Review of Ecology and Systematics, 2: 405-438.

Chambers, J. C., 1995: Relationships between seed fates and seedling establishment in an alpine ecosystem. Ecology, 76: 2124-2133. 
Day, T. A., Ruhland, C. T., Grobe, C. W., and Xiong, F., 1999: Growth and reproduction of Antarctic vascular plants in response to warming and UV-radiation reductions in the field. Ecologia, 119: 24-35.

Erhardt, A., and Jäggi, B., 1995: From pollination by Lepidoptera to selfing; the case of Dianthus glacialis (Caryophyllaceae). Plant Systematics and Evolution, 195: 67-76.

Gottfried, M., Grabherr, G., and Pauli, H., 1998: Prediction of vegetation patterns at the limits of plant life: a new view of the alpine-nival ecotone. Arctic and Alpine Research, 30: 207-221.

Grime, J. P., 2001: Plant Strategies and Vegetation Processes. New York, John Wiley and Sons, $417 \mathrm{pp}$.

Grulke, N. E., and Bliss, L. C., 1985: Growth forms, carbon allocation and reproductive patterns of high arctic Saxifrages. Arctic and Alpine Research, 27: 241-250.

Gugerli, F., 1998: Effect of elevation on sexual reproduction in alpine populations of Saxifraga oppositifolia (Saxifragaceae). Oecologia, 114: 60-66.

Gugerli, F., 2000: Fortpflanzung bei Saxifraga oppositifolia und S. biflora unter alpinen Bedingungen-Fremdbestäubung als genetische Versicherung? Bauhinia, 14: 53-65.

Günthart, A., 1926: Die Blütenbiologie der Alpenflora. In: Schröter, C. (Hrsg.), Das Pflanzenleben der Alpen. Zürich, A. Raustein, $1028-1109$.

Harper, J. L., 1990: Population biology of plants. London, Academic Press, $892 \mathrm{pp}$.

Harper, J. L., Lowell, P. H., and Moire, K. G., 1970: The shapes and sizes of seeds. Annual Review of Ecology and Systematics, 1: 320-337.

Hartmann, H., 1955: Studien über die vegetative Fortpflanzung in den Hochalpen. Jahresbericht der Naturforschenden Gesellschaft Graubündens, 86: 3-168.

Kerner, A., 1871. Der Einfluss der Winde auf die Verbreitung der Samen im Hochgebirge. Zeitschrift Deutscher Alpenverein issue of 1871: 144-172.

Kikvidze, Z., 1993: Plant species associations in the alpine-subnival vegetation patches in the Central Caucasus. Journal of Vegetation Science, 4/3: 297-302.

Kikvidze, Z., and Nakhutsrishvili, G. Sh., 1998: Facilitation in subnival vegetation patches. Journal of Vegetation Science, 9/2: 261-264.

Körner, Ch., 1993: Das "Ökosystem Polsterpflanze": Recycling and Aircondition. Biologie in unserer Zeit, 23/6: 353-355.

Körner, Ch., 1999: Alpine plant life. Berlin, Springer, 338 pp.

Körner, Ch., and de Moreas, J. A. P. V., 1979: Water potential and diffusion resistance in alpine cushion plants on clear summer days. Oecologia Plantarum, 14: 109-120.

Marchand, P. J., and Reach, D. A., 1980: Reproduction strategies of pioneering alpine species: seed production, dispersal and germination. Arctic and Alpine Research, 12: 137-146.

Müller, H., 1881: Alpenblumen, ihre Befruchtung durch Insekten und ihre Anpassung an dieselben. Leipzig, W. Engelmann, 611 pp.

Nakhutsrihvili, G. Sh., 1998: The vegetation of the Subnival Belt of the Caucasus Mountains. Arctic, Antarctic, and Alpine Research, 30: 222-226.
Rauh, W., 1939: Über polsterförmigen Wuchs. Ein Beitrag zur Kenntnis der Wuchsformen höherer Pflanzen. Nova Acta Leopoldina (Halle/Saale), 7: 272-505.

Salisbury, E., 1974: Seed size and mass in relation to environment. Proceedings of the Royal Society London: Biology, 186: 83-88.

Schütz, M., and Stöcklin, J., 2001: Seed weight differences between alpine and lowland plants? Verhandlungen der Gesellschaft für Ökologie, 31: 55.

Söyrinki, N., 1938: Studien über die generative und vegetative Vermehrung der Samenpflanzen der alpinen Vegetation PetsamoLapplands. Annales Botanici Societatis Zoologicae Botanicae Fennicae Vanamo, 11: 1-311.

Stäger, R., 1913: Beobachtungen über das Blühen einer Anzahl einheimischer Phanerogamen. Beihefte zum Botanischen Zentralblatt, 31, Abt. 2: 318-321.

Stöcklin, J., 1992: Umwelt, Morphologie und Wachstumsmuster klonaler Pflanzen-eine Übersicht. Botanica Helvetica, 102: 3-21.

Stöcklin, J., and Favre, P., 1994: Effects of plant size and morphological constraints on variation in reproductive components in two related species of Epilobium. Journal of Ecology, 82: 735-746.

Swiss Central Meteorological Institution, 1997: Report of 1996. Zürich.

Thompson, K., and Rabinowitz, K., 1989: Do big plants have big seeds? American Naturalist, 133: 722-728.

Urbanska, K. M., 1992: Populationsbiologie der Pflanzen. UTB 1631. Stuttgart, G. Fischer, 374 pp.

Urbanska, K. M., and Schütz, M., 1986: Reproduction by seed in alpine plants and revegetation research above timberline. Botanica Helvetica, 96/1: 64-90.

Venable, D. L., and Brown, J. S., 1988: The selective interactions of dispersal, dormancy and seed size as adaptations for reducing risk in variable environments. American Naturalist, 131: 360-384.

Venable, D. L., and Brown, J. S., 1993: The population-dynamic functions of seed dispersal. Vegetatio, 107/108: 31-55.

White, J., 1979: The plant as a metapopulation. Annual Review of Ecology and Systematics, 10: 109-145.

White, J., 1984: Plant metamerism. In: Dirzo, R., and Sarukhan, J. (eds.), Perspectives in plant population biology. Sunderland, Massachusetts, Sinauer, 15-47.

Zoller, H., and Lenzin, H., 2004: Survival and recruitment favored by safe site-strategy the case of the high alpine non-clonal cushions of Eritrichium nanum (Boraginaceae). Flora, 199: 398-408.

Zoller, H., Lenzin, H., and Erhardt, A., 2001: Untersuchungen zum Lebenszyklus der hochalpinen Polsterpflanze Eritrichium nanum (L.) Schrader ex Gaudin Teil 1: Blütenbiologie. Bauhinia, 15: $1-17$.

Zoller, H., Lenzin, H., and Erhardt, A., 2002: Pollination and breeding system of Eritrichium nanum (Boraginaceae). Plant Systematics and Evolution, 233: 1-14. 